\title{
URGENT ISSUES OF UKRAINE'S GREENHOUSE GAS INVENTORY
}

\author{
Shmarin S.L. ${ }^{1}$, Troyanska Ye.N. ${ }^{1}$, Denisenko I.Yu. ${ }^{2}$ \\ ${ }^{1}$ NGO "Bureau of Complex Analysis and Forecasts" \\ 60, Sichovykh Striltsiv Str., 04050, Kyiv \\ ${ }^{2}$ State Ecological Academy of Postgraduate Education and Management \\ 35, Metropolitan Vasyl Lypkivskyi Str., building 2, 03035, Kyiv \\ Sergeyshmarin1988@gmail.com,Denisenko15@ukr.net
}

\begin{abstract}
The basic element of the functioning of the GHG inventory system of Ukraine is GHG Emission Inventory, which is annually prepared to meet the obligations under United Nations Framework Convention on Climate Change. In order to provide recommendations on strengthening national GHG inventory system, last three published Ukraine's GHG Emission Inventories were analyzed to identify urgent issues on its preparation.

The results of the analysis revealed a number of systemic shortcomings during the development of the latest GHG Emission Inventories in Ukraine, which can be divided into organizational, statistical isolation and methodological issues. The following crucial issues related to Ukraine's GHG Inventory compilation were identified: the procedures of Ukraine's GHG Inventory public consultations, methodology inconsistency of GHG emission data and other state and departmental statistics, as well as lack of external peer review at the stage of draft GHG Inventory planning and preparing.

Specific recommendations how to addressed revealed week spots where provided, among which are: to improve the procedures of Ukraine's GHG Inventory preparation, to involve external experts at the stage of planning and preparation of draft GHG Inventory, as well as to introduce the practice to draw up additional technical documentation on GHG emissions in Ukraine, which should be based solely on the state and departmental statistics excluding activities at the temporarily occupied territories of Ukraine. Such a document could be prepared in the form of technical amendment to Ukraine's GHG Emission Inventory. The other option is to prepare informational note containing information on the input data and GHG emissions by each source/IPCC category of GHG emissions defined based on the initial data of official statistical reporting and its comparison with data posted on the website of the UNFCCC Secretariat.

Increasing the quality and transparency of Ukraine's GHG Inventory will lead to more accurate modeling of GHG emissions in the country, as well as ensure availability of more objective input data to plan and implement the activity on GHG emission reduction in Ukraine. Key words: climate change, GHG emissions, public consultations, methodology consistency, quality improvement.
\end{abstract}

Проблемні питання Національного кадастру антропогенних викидів із джерел та абсорбції поглиначами парникових газів в Україні. Шмарін С.Л., Троянська С.М., Денисенко І.Ю.

Базовим елементом функціонування системи обліку викидів парникових газів в Україні є Національний кадастр антропогенних викидів із джерел та абсорбції поглиначами парникових газів (надалі - Кадастр викидів ПГ), який щорічно розробляється у рамках зобов'язань за Рамковою конвенцією ООН про зміну клімату. 3 метою надання рекомендацій щодо підвищення спроможності національної системи обліку викидів парникових газів, останні три опублікованих Кадастри викидів ПГ в Україні було проаналізовано та виявлено проблемні питання їх підготовки.

За результатами аналізу було визначено ряд системних недоліків під час підготовки Кадастрів викидів ПГ в Україні, які можна розділити на організаційні питання, питання статистичної ізоляції та методологічні питання. До найбільш гострих питань підготовки Кадастрів викидів ПГ слід віднести процедури обговорення проєкту Кадастру викидів ПГ, методологічну неузгодженість даних про викиди ПГ з іншими даними офіційної та відомчої статистики, а також відсутність зовнішнього рецензування на етапі планування та підготовки проєкту Кадастру викидів ПГ.

Запропоновано шляхи усунення вищеозначених слабких місць, одними 3 яких є: удосконалення процедур підготовки Кадастру викидів ПГ, залучення зовнішніх експертів на етапі планування та підготовки Кадастру викидів ПГ, запровадження практики складання додаткової документації технічного характеру про викиди ПГ в Україні, яку буде сформовано винятково за даними державної та відомчої статистики без урахування діяльності на тимчасово окупованих територіях.

Підвищення якості підготовки Кадастру викидів ПГ дозволить коректніше проводити моделювання викидів ПГ в Україні та забезпечить наявність більш об’єктивної вихідної інформації для планування та реалізації заходів, спрямованих на скорочення викидів ПГ в Україні. Ключові слова: зміна клімату, викиди парникових газів, громадське обговорення, методологічна узгодженість, підвищення якості.

Problem definition. Ukraine is a party to the UN Framework Convention on Climate Change (UNFCCC), the Kyoto Protocol, the Paris Agreement and EU Association Agreement. Within the framework of these international agreements, Ukraine has undertaken to ensure the effective functioning of the national system for the assessment of anthropogenic emissions and absorption of greenhouse gases (hereinafter the GHG Emission Accounting System).

The basic and key component of the National GHG Inventory System is the annual inventory of greenhouse gas emissions (GHG), namely, Ukraine's GHG Emission Inventory [1], which is developed annually and is a subject to public consultations, according to the results 
of which - submitted to the UNFCCC Secretariat. After its publication, the GHG Emission Inventory is reviewed by the Expert Review Team (ERT), based on the results of which the GHG Emission Inventory is approved at the international level.

GHG Emission Inventory fulfills the following role in planning state policy and ensuring its implementation in the field of climate change and reducing the carbon intensity of Ukraine's economy:

- source of reliable information on retrospective GHG emissions in Ukraine by types of greenhouse gases and sources of their formation (IPCC categories [2]);

- documentary verified confirmation of the achieved results in the issues of GHG emission reductions;

- source of initial data for identification of the largest sources of GHG emissions and their potential for reduction in Ukraine;

- source of initial data for the formation of GHG reduction policies and measures in Ukraine, on the basis of which the following state planning documents and international reports are formed: Nationally Determined Contribution [3], National Communication and Biennial Report [4], Low Emission Development Strategy [5] etc.

The purpose of this work is to contribute to the increasing the quality of GHG Emission Inventory in Ukraine by identifying the urgent issues on its preparation and providing recommendations how to fix these week spots. To achieve the goal, last three GHG Emission Inventories, published in 2018,2019 and 2020 on the website of the UNFCCC Secretariat $[1 ; 6 ; 10]$ were analyzed.

Context. The GHG Emission Inventory is developed by the Budget Institution "National Center for Greenhouse Gas Emission Inventory" of the Ministry of Energy and Environmental Protection of Ukraine, in accordance with the annually approved plan of GHG Emission Inventory preparation, resolutions of Conference of Parties to UNFCCC. 24.CP / 19 [7], IPCC National Greenhouse Gas Inventory Guidelines, 2006 [2], taking into account the latest recommendations of the ERT [8]. A particular feature of preparation of the GHG Emission Inventory in Ukraine, which meets the requirements of Decision 24.CP / 19, is that GHG Emission Inventory takes into account GHG emissions occurring on the temporarily occupied territories, namely: certain districts of Donetsk and Luhansk regions, Autonomous Republic of Crimea and the city of Sevastopol, i.e. the activities that are not included into other state and departmental statistics of Ukraine.

The results of the analysis revealed a number of systemic shortcomings during the development (compilation) of the latest GHG Emission Inventories in Ukraine (2018-2020 years of submission), which can be divided into the following issues: organizational, statistical isolation from other data sources, methodological.

1. Organizational. Within the existing National GHG Inventory System, the procedure of public consultations is reduced to a formality and does not fulfill its function, namely - the involvement of a wide range of specialists and experts into preparation of the document. This situation is due to the fact that the Draft GHG Emission Inventory, which is posted on the website of the Ministry of Energy and Environmental Protection of Ukraine, contains the aggregate data on emissions generated both on the basis of official data (mostly generated by the State Statistics Service of Ukraine) and the activities on the temporarily occupied territories. At the same time, it is impossible to segregate the amount of emissions and data on activities on the temporarily occupied territories based on the provided information. In addition, the methodology for estimating GHG emissions on the temporarily occupied territories [9] was developed in 2014 and does not correspond to modern realities.

Thus, during the public consultations procedure, it is impossible to verify the most of emission data provided in the Draft GHG Emission Inventory and to identify potential deficiencies. As a result, the GHG Emission Inventory becomes artificially detached from the formation of statistical reporting in Ukraine.

2. Statistical isolation from other data sources. The data contained in the GHG Emission Inventory do not meet the needs for generating GHG emission estimates used to prepare / update National Communications and Biennial Reports, Low Carbon Development Strategy, etc. The modeling uses macroeconomic statistics based on official data and is incomparable with GHG emissions data, which additionally take into account activities on the temporarily occupied territories. As a result, at modeling, the specific GHG emissions are overestimated due to the fact that allegedly higher GHG emissions correspond to fewer goods produced and consumed.

3. Methodological. During the development of Ukraine's GHG Emission Inventory submitted in 2020, the independent experts weren't involved on a wide scale into estimating GHG emissions on the temporarily occupied territories and into the most recalculations in key categories, which contradicts the basic principles of reporting under the UNFCCC, whereas 2006 IPCC Guidelines for National Greenhouse Gas Inventories state - "Expert judgement on methodological choice and choice of input data to use is ultimately the basis of all inventory development".

\section{Recommendations for the preparation of the GHG} Emission Inventory 2021.

1. To change the procedures for preparing the GHG Emission Inventory. The draft GHG Emission Inventory, which is published for official consultations and provision of recommendations, should be formed only on the basis of official statistical reporting data in terms of the latest reporting year. Re-assessment of GHG emissions occurring on the temporarily occupied territories should be performed after the procedure of public consultations and after processing of the provided recommendations and remarks.

2. To update the methodology for estimating GHG emissions on the temporarily occupied territories. The 
previous methodology (developed in 2014) is outdated and does not correspond to the current state of affairs.

3. To involve independent experts with relevant experience into developing a new methodology for estimating GHG emissions on the temporarily occupied territories and into its annual modernization, as well as into the quality assurance/ quality control procedures for key sources of GHG emissions at the stage of preparation of draft GHG Emission Inventory.

4. To expend the involvement of external experts with relevant experience into quality assurance / quality control procedures for key GHG emission sources and those sources.

5. To form two versions of the GHG Emission Inventory in each reporting year. The first, taking into account GHG emissions on the temporarily occupied territories, which would actually be posted on the web- site of the UNFCCC Secretariat. The second, which is methodologically consistent with the official version posted on the website of the UNFCCC Secretariat, but the calculations of which are based on the initial data of official statistical reporting. The second version of the GHG Emission Inventory so called "Technical amendment to the GHG Emission Inventory" should be distributed on the basis of confidentiality rights among the developers of state planning documents on climate change in Ukraine.

6. The alternative to the "Technical amendment to the GHG Emission Inventory" could be an Informational Note containing information on the input data and GHG emissions by each source/IPCC category of GHG emissions defined based on the initial data of official statistical reporting and its comparison with data posted on the website of the UNFCCC Secretariat.

\section{References}

1. Ukraine's Greenhouse Gas Inventory 1990-2018. The Ministry of Energy and Environmental Protection of Ukraine. Kyiv. 2020. Available at: https://menr.gov.ua/files/docs/Zmina klimaty/2020/Ukraine NIR 2020\%20draft.pdf.

2. IPCC 2006, 2006 IPCC Guidelines for National Greenhouse Gas Inventories, Prepared by the National Greenhouse Gas Inventories Programme, Eggleston H.S., Buendia L., Miwa K., Ngara T. and Tanabe K. (eds). Published: IGES, Japan. Available at: https://www.ipcc-nggip.iges.or.jp/public/2006gl/voll.html.

3. Ukraine's First Nationally Determined Contribution. The Ministry of Environment and Natural Resources of Ukraine. Kyiv. 2016. p. 5. Available at: https://www4.unfccc.int/sites/ndcstaging/PublishedDocuments/Ukraine $\% 20$ First/Ukraine $\% 20$ First $\%$ 20NDC.pdf.

4. Ukraine's Sixth National communication and First Biennial Report (in Rusuan). The Ministry of Environment and Natural Resources of Ukraine. Kyiv. 2013. p. 342. Available at: https://unfccc.int/sites/default/files/resource/U\%206nc_v7_final_\%5B1\%5D.pdf.

5. Ukraine 2050 Low Emission Development Strategy. Ministry of Ecology and Natural Resources of Ukraine. 2018. Kyiv. P. 76. Available at: https://unfccc.int/sites/default/files/resource/Ukraine_LEDS_en.pdf.

6. Ukraine's Greenhouse Gas Inventory 1990-2017. Ministry of Ecology and Natural Resources of Ukraine. 2019. Kyiv. P. 542. Available at: https://unfccc.int/documents/195605.

7. Report of the Conference of the Parties the United Nation's Framework Convention on Climate Change on its nineteenth session. (24/CP.19). - Warsaw. - 2013. - P. 54. Available at: https://unfccc.int/resource/docs/2013/cop19/eng/10a03.pdf.

8. Report on the individual review of the annual submission of Ukraine submitted in 2019. The Expert Review Team. Bonn. 2020. Available at: https://unfccc.int/sites/default/files/resource/arr2019_UKR.pdf.

9. Report on the research work "Preparation of proposals and recommendations on the accounting of greenhouse gas emissions and removals in territories with special status (4 administrative units) by the IPCC sectors" [confidential] (in Ukrainian).

10. Ukraine's Greenhouse Gas Inventory 1990-2016. Ministry of Ecology and Natural Resources of Ukraine. 2018. Kyiv. P. 519. Available at: https://unfecc.int/documents/106947. 